\title{
THE SUPREME COURT AND THE CREDENTIALS CHALLENGE CASES: ASK A POLITICAL QUESTION, YOU GET A POLITICAL ANSWER
}

During the 1972 Democratic Convention, the Supreme Court was asked to overrule two Credentials Committee decisions to seat challenging slates of delegates from Illinois and California. The Court faced an unattractive choice. Both Senator McGovern, the eventual nominee, and a coalition of his opponents hoped to ensure victory at the Convention through a favorable judicial decision. The District of Columbia Circuit ruled on the merits, but in O'Brien v. Brown, the Supreme Court stayed the circuit court judgment and withheld action on the petitions for certiorari. ${ }^{1}$ The day after the Supreme Court decided $O$ 'Brien, an Illinois trial court enjoined the Illinois challenging delegation from participating in the Convention, and an Illinois appellate court upheld the injunction in Wigoda v. Cousins. ${ }^{2}$

There has been a great deal of comment on the $O^{\prime}$ Brien opinion, ${ }^{8}$ inuch of it critical of the Court's refusal to decide the cases on their merits. The Court will, however, soon have an opportumity to answer some of these crities, simce it has agreed to review the Illinois court's opinion in Wigoda.

This Comment reviews the issues presented by the O'Brien and Wigoda cases. Part I surveys the factual background from which the (1974)

1. 409 U.S. 1, 3-5 (1972).

2. 14 III. App. 3d 460, 302 N.E.2d 614 (1973), cert. granted, 415 U.S. 956

3. See Blumstein, Party Reform, The Winner-Take-All Primary, and the California Delegate Challenge: The Gold Rush Revisited, 25 VAND. L. REv. 975 (1972) [hereinafter cited as Blumstein]; Raymar, Judicial Review of Credentials Contests: The Experience of the 1972 Democratic National Convention, 42 GEO. WASH. L. REV. 1 (1973) [hereinafter cited as Raymar]; Note, Judicial Intervention in National Political Conventions, 59 CoRnell L. Rev. 107 (1973); Note, One Person-One Vote: The Presidential Primaries and Other National Convention Delegate Selection Processes, 24 HAST. L.J. 257 (1973); Comment, O'Brien v. Brown: The Politics of Avoidance, 58 Is. L. REv. 432 (1972); Note, Mandates of the National Political Party Clash with Interests of the Individual States as the Party Executes Its Policy by Abolition of State Delegate Selection Results: Legal Issues of the 1972 Democratic Convention and Beyond, 4 LoY. U.L.J. (Chi.) 137 (1973) [hereinafter cited as Mandates]; Note, Judicial Intervention in the Presidential Candidate Selection Process: One Step Backwards, 47 N.Y.U.L. REv. 1184 (1972) [hereinafter cited as One Step Backwards]; Note, Constitutional Law: Conventional Reluctance or Doctrinal Departure? The Political Questions Doctrine, 51 N.C.L. REv. 290 (1972); Commeut, Political Parties, Courts and Political Question Doctrine: New Developments, 52 ORE. L. REV. 269 (1973); Comment, The Application of Constitutional Provisions to Political Parties, 40 TENN. L. REv. 217 (1973) [hereinafter cited as Application]. 
two cases arose. Part II analyzes the Supreme Court decision in $O$ 'Brien with particular emphasis on the Court's suggestion that intraparty disputes involve nonjusticiable political questions. Part III examines the theoretical bases of the political questions doctrine and finds that they do not apply to intraparty credentials disputes. Part IV discusses the interests which militate in favor of judicial intervention in credentials disputes. Finally, Part V suggests some tests which courts might use in deciding the merits of cases like O'Brien and Wigoda.

\section{I}

\section{The Political Setting}

Early in the race, Senator McGovern's presidential campaign was a long shot, but successes in some early primary states gave considerable momentum to his bid for the Democratic nomination. $\mathrm{He}$ emerged as the man to beat after he won 271 convention delegates in California's "winner-take-all" primary, and he moved even closer by capturing 256 of New York's 278 delegates in the June 20th primary. McGovern, however, had not fared so well in other large industrial states. In the key state of Illinois, for example, McGovern supporters had been effectively frozen out of the delegate selection process by Chicago Mayor Richard J. Daley's infamous political machine. ${ }^{4}$

McGovern's position was strong, but his opponents were not ready to concede the nomination. While McGovern was thanking his victorious New York campaign workers for their efforts, supporters of other candidates were planning to challenge the credentials of the proMcGovern California delegation. At the same time, McGovern forces in Chicago, led by Alderman William Singer and the Reverend Jesse Jackson, planned to challenge the 59 so-called "Daley delegates" from northern Illinois. ${ }^{5}$

The challenge to the California delegation was based on the theory that the "winner-take-all" aspect of the state's primary law violated the spirit of party reform mandated by a resolution of the 1968 Convention whicl1 assured that all Democrats would have a "full and timely opportunity" to participate in the process of selecting delegates to the 1972 Convention. In particular, the resolution abolished the unit rule at all stages of the delegate selection process and required that all feasible efforts be made to assure that delegates were elected through pro-

4. See T. White, The Making of The President 1972, 122-40, 218 (Bantam ed. 1973) [hereinafter cited as WHITE].

5. Id. at 174-75. For a good discussion of the legal issues involved in the challenges, see Brown v. O'Brien, 469 F.2d 563 (D.C. Cir.), judgment stayed, 409 U.S. 1, vacated, 409 U.S. 816 (1972). See also Blumstein, supra note 3; Raymar, supra note 3; Mandates, supra note 3. 


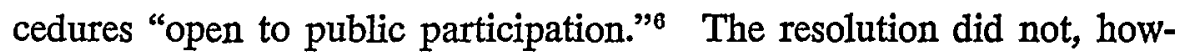
ever, require the abolition of "winner-take-all" primaries. A commission on party reform (the McGovern, later Fraser, Commission), which set guidelines for carrying the resolution into effect, had specifically rejected a proposal to abolish "winner-take-all" primaries for the 1972 campaign. The guideline concerning fair representation (Guideline B-6), adopted by the National Committee in February, 1971, recommended that "winner-take-all" primaries be abolished, but specifically did not require state parties to do so. The Call to the 1972 Democratic Convention maintained this same distinction. ${ }^{7}$

The Credentials Committee of the 1972 Convention appointed Burke Marshall, Yale law professor and former Deputy Attorney General, as hearing examiner for the California credentials challenge. Marshall determined that California had not been required to abolish its "winner-take-all" primary and that the results of the primary, awarding all of the state's delegates to McGovern, were valid. On June 29, with California's delegates on the Credentials Committee disqualified from voting, ${ }^{8}$ the full committee rejected Marshall's decision. The Committee voted to apportion California's delegates among all the candidates entered in the June 6 primary according to the percentage of the vote they had received.

The next day, the Credentials Committee considered a challenge to the Illinois delegation. Alderman Singer, Reverend Jackson, and the other "uncommitted" challengers argued that the Daley delegates had violated party rules by "slate-making" and by under-representing various demographic groups. The claims of the Singer-Jackson group were all upheld by the learing examiner, Cecil Poole, one-time U.S. Attorney for northern California. Stung by their defeat on the California challenge, the McGovern forces on the Credentials Committee voted to unseat Mayor Daley and 58 other delegates from Cook County.

Both ejected delegations rushed to court to obtaim reversals of the Credentials Committee decisions. ${ }^{9}$ The district court on July 3 denied

6. Brown v. O'Brien, 469 F. 2 d 563, 568 (D.C. Cir. 1972).

7. Id. at 567 .

8. The Conveution rules precluded a challenged delegation from voting on its own case. See WHITE, supra note 4 , at 173.

9. Before the Credentials Committee or the hearing examiner had taken any action on the challenge, the challenged Illinois delegates filed an action against the Democratic Party in the district court of the District of Columbia seeking to have the party guidelines declared unconstitutioual and to have recognition of the Singer-Jackson group as an alternative delegation enjoined. The district court issued an order which reached the merits of the constitutional claims. On appeal, the circuit court vacated the order on the ground that the Credentials Committee had taken no action and the suit was premature. Keane v. National Democratic Party, Civil No. 1010-72 (D.D.C. June 19, 1972), vacated, Civil No. $72-1562$ (D.C. Cir. June 20, 1972).

Once the Credeutials Committee had acted, the ousted Illinois delegates filed an- 
relief to both ousted delegations on the ground that no justiciable questions laad been raised. ${ }^{10}$ Only two days later, the District of Columbia Circuit Court of Appeals reversed the district court's decision on the complaint of the ousted California delegates, ordering that all of McGovern's California delegates be seated, and affirmed the district court's refusal to grant relief to the ousted Illinois delegates. ${ }^{11}$

On July 6, the losing parties filed petitions for certiorari and applications to stay the circuit court judgment pending action on the petitions with the Supreme Court. On July 7, the Court, in a per curiain opinion, granted the stays but took no action on the petitions for certiorari. ${ }^{12}$ The Court stated that it liad not acted on the petitions because it was so near the opening of the Convention that there was not adequate time to consider the important issues presented by the litigants. ${ }^{13}$ In ruling on the applications to stay the circuit court judgment, the Court weighed three basic factors:

(a) [w] hether irreparable injury may occur absent a stay; (b) the probability that the Court of Appeals was in error in holding that the merits of these controversies were appropriate for decision by federal courts; and (c) the public interests that may be affected by the operation of the judgments of the Court of Appeals. ${ }^{14}$

The stays were granted because (a) absent a stay, the circuit court judgment would deny to the Democratic National Convention its traditional power to pass on the credentials of the delegates in question; (b) the Court "entertained grave doubts" about the circuit court's judgment on the issues of whether the case was a non-justiciable political question, whether the action of the Credentials Committee is state action, and the reach of the due process clause in such a case; and (c) the Court recognized a "large public interest in allowing the political

other suit seeking essentially the same relief. The district court consolidated this case with the earlier one. See Brown v. O'Brien, 469 F.2d 563, 571 n.5 (D.C. Cir. 1972).

10. Keane v. National Democratic Party, Civil No. 1010-72 (D.D.C. July 3, 1972); Keane v. Cousins, Civil No. 1320-72 (D.D.C. July 3, 1972); Brown v. O'Brien, Civil No. 315-72 (D.D.C. July 3, 1972).

11. Brown v. O’Brien, 469 F.2d 563 (D.C. Cir. 1972).

12. O'Brien v. Brown, 409 U.S. 1 (1972).

On October 10, the Supreme Court granted certiorari in the California case, vacated the judgment, and remanded to the circuit court with orders to dismiss as moot. O'Brien v. Brown, 409 U.S. 816 (1972). At the same time, the Court granted certiorari in the Illiniois case, vacated the judgment, and remanded to the circuit court for a determination of whether the case was moot. Keane v. National Democratic Party, 409 U.S. 816 (1972). On February 16, 1973, the court of appeals determined that the case was moot insofar as it involved the right to represent the Illinois Democrats at the Convention seven months earlier. Keane v. National Democratic Party, 475 F.2d 1287, 1288 (D.C. Cir. 1973).

13. O'Brien v. Brown, 409 U.S. 1, 3 (1972).

14. Id. 
processes to function free from judicial supervision."15 The Court acknowledged that a stay of the appellate court's decision would probably preclude judicial review of the final action taken by the Convention, in that the cases would become moot once the Democrats had chosen their nominee and the national campaign was underway. ${ }^{10}$

The ousted Daley delegates continued to press for judicial action before the balloting at the Convention. On July 8, the day following the Supreme Court's decision in O'Brien and two days before the start of the Convention, the Daley delegates moved in the Circuit Court of Cook County (lllinois) to enjoin the Singer-Jackson group from acting or purporting to act as delegates to the Democratic Convention. ${ }^{17}$ Judge Covelli of the Cook County Court issued the requested mjunction, entering findings of fact but no formal opimion. ${ }^{18}$ The SingerJackson delegates did not appeal the injunction, but they nevertheless were seated as Illinois delegates to the Convention on July $10 .^{10}$ On August 2, after the Convention was over, the Daley delegates moved for supplemnental relief, and Judge Covelli issued a second injunction, this time restraining the Singer-Jackson group from participating as de1egates in post-Convention party affairs, including a caucus to select the Illinois representatives to the Denocratic National Committee. ${ }^{20} \mathrm{He}$ also ordered the Singer-Jackson delegates to show cause why they should not be held in contempt of court for violating his July 8 injunction; but the contempt proceedings were held up while the Singer-Jackson delegates appealed Judge Covelli's orders. ${ }^{21}$

The Illinois appellate court upheld the trial court's dccisions. It determined that neither the Supreme Court nor the circuit court decision in $O^{\prime}$ Brien barred Judge Covelli's actions, ${ }^{22}$ rejecting the argument that $O^{\prime} B r i e n$ held that the Convention should decide the credentials

15. Id. at 3-5.

16. Id. at 5 .

17. Legal action by the Daley slate had actually been eommenced months earlier, when Singer and Jackson first filed their challenge with the Credentials Committee. See note 9 supra. This suit and several other related actions bounced between the Illinois state courts and the federal courts in Illinois and the District of Columbia. It was only after the Supreme Court had stayed the District of Columbia Circuit decision in Keane that the Cook County judges decided they were able to issue the injunction against the Singer-Jackson delegates' participating in the Convention. This complex litigation is discussed in Wigoda v. Cousins, 14 Ill. App. 3d 460, 462-66, 302 N.E.2d 614, 617-24 (1973). See also Mandates, supra note 3, at 141-42 n.18.

18. See Wigoda v. Counsins, 14 I11. App. 3d 460, 466, 302 N.E.2d 614, 621 (1973). See also Mandates, supra note 3, at 154.

19. See Wigoda v. Cousins, 14 I11. App. $3 \mathrm{~d}$ 460, 466, 302 N.E.2d 614, 621 (1973).

20. See id. at $466-67,302$ N.E.2d at $621-22$.

21. Los Angeles Times, March 5, 1974, at 12, col. 1.

22. Wigoda v. Counsins, 14 III. App. 3d 460, 467, 302 N.E.2d 614, 622-23 (1973). 
challenges free from judicial intervention. The court in Wigoda failed, however, to reconcile its precisely drawn conclusion ${ }^{23}$ with the Supreme Court's statement in O'Brien that "the convention itself is the proper forum for determining intraparty disputes as to which delegates shall be seated. ${ }^{24}$

Faced with possible contempt citations for violating the injunctive order, the Singer-Jackson delegates petitioned the Supreme Court for certiorari to review the Wigoda decision. Earlier this year, the Court agreed to hear the case. ${ }^{25}$

Wigoda raises several critical questions. Perhaps nost significant is the recurrence of an issue which the Supreme Court raised but did not settle in O'Brien-whether credentials disputes and similar intraparty matters present nonjusticiable political questions. Also important are the issues of whether state law exclusively governs the selection of delegates to national party conventions, notwithstanding applicable party rules, and whether the Illinois court's intervention into the Convention's credentials process violated constitutional rights of political association. ${ }^{26}$ But the political questions issue must be resolved first. If intraparty disputes, like those involved in O'Brien and Wigoda, present political questions, the cases are nonjusticiable and the other issues are not reached.

II

\section{What the SUPreme Court SaId in O'Brien About Political Questions}

Wigoda gives the Supreme Court the opportunity to decide the issue of whether intraparty disputes are nonjusticiable political questions. This section of the Comment will attempt to analyze O'Brien as a basis for predicting how the court will resolve the issue in Wigoda.

A literal reading of $O^{\prime} B r i e n$ indicates that the Court did not decide the political questions issue. The issue only arose as one of three factors the Court weighed in deciding whether or not to stay the circuit

23. In the Wigoda opinion, the court said:

The [O'Brien] opinion does not say "free from judicial intervention," but says "absent judicial intervention the Convention could decide to accept or reject with modification, the proposals of its Credentials Committee." The Court was discussing the Federal courts and does not mention State laws, election of delegates or their rights, or the rights, or the jurisdiction of State courts over their delegates. It must be recognized that the Circuit Court of Illinois was not intervening in the Convention, but only exercised its jurisdiction over the IlliId. nois delegates and challengers under the Illinois Elections Code.

24. O'Brien v. Brown, 409 U.S. 1, 4 (1972).

25. Cousins v. Wigoda, cert. granted, 415 U.S. 956 (1974).

26. Id. 
court judgment. ${ }^{27}$ One factor was the probability that the lower court had erred in deciding that $O^{\prime} B r i e n$ did not present a nonjusticiable pohitical question. ${ }^{28}$

The Court began its analysis by pointing out: "No holding of this Court up to now gives support for judicial intervention in the circumstances presented here, involving as they do, relationships of great delicacy that are essentially pohitical in nature."20 In support of this statement, the Court first cited Luther v. Borden, ${ }^{30}$ the case which is commonly said to have originated the political questions doctrine. ${ }^{31}$ The Court then noted that judicial intervention into party politics has "traditionally been approached with great caution and restraint,"32 and, in support of this statement, cited four cases, ${ }^{33}$ the first of which specifically held that a challenge to Minnesota's delegate selection procedures presented a nonjusticiable political question. ${ }^{34}$

The Court continued its analysis by pointing out that historically disputes over the selection of delegates have been resolved by the party conventions. The Court perceived O'Brien as presenting "highly important" questions of whether the credentials disputes are justiciable and whether the Credentials Committee decision was state action. ${ }^{35}$

27. See text accompanying notes 18-21 supra.

28. 409 U.S. at 3.

29. Id. at 4.

30. 7 How. 1 (1849). In Luther v. Borden, the Court asserted that the Constitution left the questiou of whether a state had a republican form of government to the determination of Congress.

31. Professor Frank argues that the political questions doctrine of Luther v. Borden was antedated by Ware v. Hylton, 3 U.S. (3 Dall.) 199 (1796), holding that the Court would not pass on whether a treaty had been broken, and by Martin v. Mott, 25 U.S. (12 Wheat.) 19 (1827), holding that the President had exclusive power to determine whether the militia should be called out. But Frank concedes that the Court itself thought that Luther v. Borden presented a question of first impression. Frank, Political Questions, in SUPREME COURT AND SUPREMe LAW 37 (L. Cahn ed. 1954) [hereinafter cited as Frank].

32. O'Brien v. Brown, 409 U.S. 1, 4 (1972).

33. Irish v. Democratic-Farmer-Labor Party, 399 F.2d 119 (8th Cir. 1968); Lynch v. Torquato, 343 F.2d 370 (3d Cir. 1965); Smith v. State Executive Comm., 288 F. Supp. 371 (N.D. Ga. 1968). Cf. Ray v. Blair, 343 U.S. 214 (1952).

34. Irish v. Democratic-Farmer-Labor Party, 399 F.2d 119, 121 (8th Cir. 1968). Under Minnesota law, delegates to national party conventions were selected by a caucus procedure, with elections held successively in precinct, county, district and state caucuses. Only the precinct elections were held according to one person, one vote principles, but the court refused to extend the one person, one vote rule to caucuses beyond the precinct level, giving four reasons: (1) courts are reluctant to imterfere in internal party affairs, at least where "There is nothing . . . with racial overtones or anything akin thereto;" (2) any element of malapportionment had come about by action of delogates properly elected on a one man, one vote basis to the precinct caucuses; (3) it was virtually impossible for the court to fashion an appropriate remedy in view of the circumstances; and (4) the case presented "a non-justiciable political question." Id. at 12021.

35. O'Brien v. Brown, 409 U.S. 1, 4 (1972). 
The Court concluded: "[W]e entertain grave doubts as to the action taken by the Court of Appeals." 36

Thus O'Brien did not resolve the political questions issue; the most which can be said of the case is that the Court held the circuit court was probably in error in regarding the case as justiciable. But this was not even the only ground for the decision. As a second factor to be weighed in deciding whether to stay the circuit court judgment, the Court suggested that allowing the judgment to stand would deprive the full convention of its traditional power to rule on credentials challenges. The third factor was the public interest in allowing the political process to operate free from judicial intervention. In addition, the Court withheld action on the petitions for certiorari, saying that it did not have time to decide judiciously the important issues involved in the case. ${ }^{37}$

The Court's discussion of these other issues left many questions unanswered. For example, when would be an appropriate time to decide the cases? The Court suggested that the lower court's judgment should be stayed because the full Convention could air the disputes and might rectify the errors of its Credentials Committee. But what if the errors were not rectified in the alternative forum? ${ }^{38}$ Would the Court decide the case then-in the interim between the vote on the seating of delegates and the vote on the presidential nomination? At that point, the Court would have even less time to decide the issues. Would the Court decide the case after the Convention had designated a presidential nominee? By that time the case might be moot, as the Court's opimion suggested, or, as Marshall's dissenting opinion indicated, the case would not be moot and reversal of the Credentials Committee decision would require declaring the acts of the Convention null and void. As Justice Marshall pointed out, the Court lield, in effect, that even if the questions presented were not political, the timing and the posture of the cases required the Supreme Court to "defer" to the Deinocratic Party. ${ }^{39}$

In order to avoid "deferring," the appropriate time to entertaim a case sucl as $O^{\prime} B r i e n$ is immediately after the decision of the Creden-

36. Id. at 5 .

37. Id. at 3-5.

38. The full convention voted to seat the entire McGovern slate from California and also to seat the Singer-Jackson challengers from Illinois. This achieved the same result that would had been accomplished if the Supreme Court had let stand the court of appeals judgment in $O^{\prime} B r i e n$. It hardly needs to be noted, however, that the convention was not motivated by the saine considerations that led the court of appeals to this result. In order to win on both the California and Illinois challenges, the McGovern forces in the convention had to make significant compromises, notably on a challenge that had been brought by the Women's Caucus against the male-dominated South Carolina delegation. See WHITE, supra note 4, at 182-83; N. MaILER, ST. GEORGE AND THE GODFATHER 42-46 (Signet ed. 1972).

39. O'Brien v. Brown, 409 U.S. 1, 8-9 (1972) (Marshall, J., dissenting). 
tials Committee. Judges Bazelon, Fahy, and MacKinnon, who decided the credentials cases for the District of Columbia Circuit Court of Appeals, indicated that decision in these cases was not inerely appropriate but imperative. ${ }^{40}$ The Illinois appellate court in Wigoda, while disagreeing with the circuit court in O'Brien on the ends to be achieved, certainly agreed that the powers of the courts should be invoked in order to safeguard the electoral process. ${ }^{41}$

Even though the political questions point is not the holding of $O$ 'Brien according to a literal reading, it can be argued that it unust be the holding as a practical matter because of the underlying weaknesses of the other ostensible grounds for the decision. Some courts and commentators seem to have adopted this view. ${ }^{42}$ One federal district court stated that O'Brien "reaffirmed the validity of the political questions doctrine." 43 Another federal court, in a case involving the selection of Delaware's delegates to the Republican convention, cited O'Brien for the proposition that intraparty disputes are "highly 'political' in character."

The most important interpretation of $O^{\prime} B r i e n$, holding that intraparty disputes are "political questions," is Justice Rehnquist's opimion in Republican State Central Committee v. Ripon Society, Inc. ${ }^{46}$ Sitting as circuit justice, he stayed an injunction issued by the district court for the District of Columbia that restrained the Republican Convention from adopting a delegate apportionment scheme which favored primarily "Republican" states. Drawing heavily on O'Brien, Justice Rehnquist noted the case's lack of "ripeness" as a ground for granting the stay. But more significant is his reference to the "political questions" language in $O^{\prime} B r i e n$ and his assertion that the district court would not have intervened in the intraparty dispute if it liad had "the benefit of this Court's writing in O'Brien at the time it entered its order and injunction." ${ }^{48}$ The opinion in Ripon Society suggested that when the Supreme Court said in O'Brien, "[T]

40. Brown v. O'Brien, 469 F.2d 563, 570 (1972).

41. 14 III. App. $3 d$ at 476,302 N.E.2d at 628 .

42. See, e.g., Republican State Central Comm. v. Ripon Soc'y, Inc., 409 U.S. 1222, 1225-26 (Rehnquist, Circuit Justice, 1972); Rayman, supra note 3, at 1518; Mandates, supra note 3, at 154; Comment, Political Parties, Courts, and the Political Question Doctrine, 52 ORE. L. REv. 269, 279-82 (1973). Cf. Application, supra note 3.

43. Atlee v. Laird, 347 F. Supp. 689, 700 (E.D. Pa. 1972). The court says: "At least one commentator had written that Powell [v. McCormack, 395 U.S. 486 (1969)] had completely undermined the doctrine. [The Supreme Court 1968 Term, 83 HARv. L. REv. 7, 68 (1969).] The discussion of political questions in O'Brien should serve to dispel any notion that the doctrine has disappeared." 347 F. Supp. at 700 n.14.

44. Redfearn v. Repulican State Comm., 362 F. Supp. 65, 70 (D. Del. 1973).

45. 409 U.S. 1222 (Rehnquist, Circuit Justice, 1972). See One Step Backwards, supra note 3 , at $1225-27$.

46. 409 U.S. at 1225. 
forum for determining intraparty disputes as to which delegates shall be seated," $"$ it meant exactly what it said.

The Illinois appellate court did not read O'Brien this way. Its conclusion on the subject was that "[o]nce elected, any question of the delegates' qualifications to hold office is beyond the authority of party functionaries; it is a legal right properly protected by the courts."48 But if $O^{\prime} B r i e n$ ineans that intraparty disputes are political questions, as the above analysis indicates, then the Supreme Court will reverse the Illinois decision in Wigoda. Is the Ilinois court "right" or is the Supreine Court "right" about the justiciability of the issues in cases like O'Brien and Wigoda? The Supreme Court of course, will have the last word on the inatter, but this Comment argues, in the next section, that the Supreme Court's position in O'Brien lacks any real theoretical basis.

III

\section{The Theoretical Bases of the Political Questions Doctrine}

The difference of opinion between Justice Marshall, in dissent, and the Supreme Court inajority in O'Brien represents a basic disagreement over the nature of the political questions doctrine. The majority position stems from a belief that there is a "large public interest in allowing the political processes to function free from judicial supervision"40 and that judicial intervention in the circumstances of the O'Brien case involves relationships of great delicacy that are essentially political in nature." Marshall argued, on the other hand, that a "question is not 'political' in the jurisdictional sense merely because it involves the operations of a political party." "51 The only political questions, in Marshall's view, are those which lead the Court into a direct conflict with the executive or legislative branch of the federal government. Marshall concludes that "courts decline to decide pohtical questions out of deference to the separation of powers." 52

The majority and dissenting opinions in $O^{\prime} B r i e n$ thus resurrect an old academic debate over the purpose of the political questions doctrine -a debate closely tied to the overall concept of judicial review. ${ }^{53}$ The two schools of thought on judicial review are characterized by the positions of Professor Wechsler and Judge Hand in their famous inter-

47. O'Brien v. Brown, 409 U.S. 1, 4 (1972).

48. Wigoda v. Cousins, 14 III. App. 3d 460, 476, 302 N.E.2d 614, 628 (1973).

49. 409 U.S. at 5.

50. Id. at 4.

51. Id. at 11 (Marshall, J., dissenting).

52. Id.

53. See Scharpf, Judicial Review and the Political Question: A Functional Analysis, 75 YALE L.J. 517, 518-19 (1966) [hereinafter cited as Scharpf]. 
change. ${ }^{54}$ Both schools of thought assume an inherent connection between the political questions doctrine and judicial review.

The Wechsler position, which might be characterized as the strict view, contends that courts may dismiss a question as "political" only when the Constitution specifically delegates judgment on that question to a coordinate brancli of the federal government. Courts do not enjoy broad discretion to abstain or intervene. Rather, Wechsler's approach requires a careful reading of the Constitution, not a sniffing of the political winds. Only when the Constitution places an issue-foreign policy, for example-within the exclusive province of one of the "political" branches can the courts dismiss a question as "political." 55

Judge Hand is perhaps the chief spokesman for the opposing position, which might be characterized as the discretionary view. ${ }^{50}$ Hand argues that the Court has traditionally ignored John Marshall's famous remark in Marbury v. Madison that "[i]t is einphatically the province and duty of the judicial department to say what the law is,"57 failing to recognize a duty to render a decision in every case that presents a constitutional question. The Court has inherent discretion to abstain from using its powers of judicial review and can exercise this discretion by declaring constitutional questions before it to be political."

Professor Bickel, another proponent of the discretionary view, argues that during periods of "political flux" the courts may want to avoid enforcement of an outmoded legal principle in order to allow adjustment of political forces. The courts cannot determine by strict constitutional interpretation whether a question is political; that determination may require the exercise of judicial prudence, not mechamical application of legal principle. ${ }^{59}$

The Wechsler view was the predominant position of the Court during the Warren years, ${ }^{60}$ but, in suggesting that O'Brien presented

54. See L. HAND, The BILL of Righrs 1-30 (1958); H. Wechsler, Toward Neutral Principles of Constitutional Law, 73 Harv. L. Rev. 1 (1959), in Principles, Polmtrcs AND FUNDAMENTAL LAW 1 (1961) [hereinafter cited as Wechsler].

55. Wechsler, supra note 54, at 9.

56. Professor Scharpf refers to this position, rather pejoratively, as the "opportunistic" position. Scharpf, supra note 53, at 552 .

57. 5 U.S. (1 Cranch) 137,177 (1803).

58. L. HAND, THE BILL of Rights 15-18 (1960). The Court also has other techniques of avoidance: a denial of certiorari, a finding of no real case or controversy between the parties, or a determination that petitioner lacks standing to sue. BICKEL].

59. A. Bicket, The Least Dangerous Branch 70 (1962) [hereinafter cited as

60. For example, in Baker v. Carr, 369 U.S. 186, 217-30 (1962), Justice Brennan, writing for the nuajority, argued that if the plaintiffs had brought their plea for reapportionment of the Tennessee legislature nnder the Guaranty Clause, the question would be political and non-justiciable because the Constitution delegates the guaranty of a republican form of state government to the determination of the pohitical branches. But 
a nonjusticiable political question, the Court implicitly rejected this approach in favor of the discretionary view. Although it offers no theoretical rationale for its allegiance to the discretionary view, the Court asserts that the public interest is best served when the political process is free from judicial supervision. ${ }^{61}$

Several reasons have been offered over the years to support the discretionary view of the political questions doctrine. First, decisions by courts im political mattcrs may prove ineffectual. Second, courts often lack the information necessary to make a judgment on political matters. Third, the questions presented are "inherently political" and incapable of judicial resolution. Fourth, judges cannot always construct manageable standards to resolve the political dispute presented. Fifth, it is sometimes politically expedient for the Court to abstain from deciding a case. The remainder of this section examines each of these reasons to determine whether any of them support the Court's decision in O'Brien.

\section{A. The Ineffectuality of a Judicial Decision on Political Matters}

A fear commonly expressed by scliolars supporting the discretionary view is that the Court's opimion might be ignored if it took a position on a politically controversial issue. ${ }^{62}$ Proponents stress that judicial prestige is a precious asset, not to be squandered carelessly or endangered by involvement in political controversies where the Court's effectiveness is in doubt. Accordingly, risks should be taken only when the stakes are high-as in the desegregation cases. ${ }^{63}$

This rationale does not support the decision in O'Brien, however; no evidence suggests that the Court abstained from a decision on the

the Court concluded: "[A]ppellants' claim that they are being denied equal protection is justiciable, and if 'discrimination is sufficiently shown, the right to relief under the equal protection clause is not diminished by the fact that the discrimination relates to political rights.' Snowden v. Huglies, 321 U.S. 1, 11." 369 U.S. 209-10. The Court adopted the strict view of the political questions doctrine even more clearly in Powell v. McCormack, 395 U.S. 486 (1969), where the Court determined that the expulsion of a member of Congress presented a justiciable controversy. 395 U.S. at 518-49. See Note, The Political Questions Doctrine and Adam Clayton Powell, 31 Albany L. Rev. 320 (1967).

61. 409 U.S. at 5; cf. Finkelstein, Judicial Self-Limitation, 37 HARV. L. REv. 338, 345 (1924) [hereinafter cited as Finkelstein].

62. See Baker v. Carr, 369 U.S. $267-70$ (1962) (Frankfurter, J., dissenting); Field, The Doctrine of Political Questions in the Federal Courts, 8 MINn. L. REv. 485, 511 (1924); Jaffe, Standing to Secure Judicial Review: Public Actions, 74 Harv. L. REv. $1265,1306-07$ (1961) [hereinafter cited as Jaffe].

Professor Scharpf refutes the argument that one of the functions of the political questions doctrine is to allow courts to avoid controversial issues on which their judginent might not be accepted as authoritative. Scharpf, supra note 53, at 550-53.

63. Jaffe, supra note 62 , at 1307. 
merits for fear that a Supreme Court ruling would go unheeded by the Convention delegates. ${ }^{64}$ Concern for the Court's prestige seems to be misplaced, since its failure to decide may have had the same detrimental effect as a decision on the merits. The Court certainly did not satisfy the contesting parties by its refusal to decide the case. Since all the parties to the credentials dispute would have abided by the Supreme Court's judgment, abstention may have made the justices appear ineffectual where the effectiveness of their judgment had not been brought into question.

\section{B. Lack of Information}

Supporters of the discretionary view sometimes contend that courts may lack the information necessary to decide a "political" question. ${ }^{65}$ This rationale has been cited as one reason for judicial avoidance of questions involving sensitive foreign policy information. ${ }^{\circ 8}$ It has also been invoked where complex domestic problems-notably, legislative reapportionment-have been involved. ${ }^{67}$ Following Baker v. $C a r r,{ }^{68}$ however, courts have been actively involved in legislative reapportionment, and lack of information is no longer a compelling basis for judicial abstention in such cases. ${ }^{69}$

This rationale cannot justify the decision in O'Brien; since the courts are capable of marshalling the information required to solve the intricate problems of malapportioned legislatures, their capability to oversee the simpler problems involved in the delegate selection procedures of the political parties should not be in doubt. Moreover, the cases had been briefed and argued before the Convention's Credentials Committee, its hearing examiners, the district court, and the court of appeals. The records from all of these hearings were available to the justices, as were the reasoned opimions of the lower courts. Thus, the

64. This argument might be more forceful when applied to the Illinois appellate court's opinion in Wigoda. There the court's order was disobeyed. However, it must be remembered that the Illinois injunction was issued only one day after the Supreme Court suggested in $O^{\prime} B r i e n$ that courts should not involve themselves in delegate credentials disputes. The authority of the Illinois court to issue an injunction on behalf of the Daley delegates was very doubtful. Had there been no doubt about the authority of the Illinois court to issue the injunctions involved in Wigoda and to back up the injunctions with contempt citations, the decision of the court would probably have been obeyed.

65. Frank, supra note 30, at 38-39; Scharpf, supra note 53, at 567-73.

66. Cf. Chicago \& Southern Airlines, Inc. v. Waterman S.S. Corp., 333 U.S. 103, 111 (1948).

67. Cf. Colgrove v. Green, 328 U.S. 549 (1946); Baker v. Carr, 369 U.S. 186, 326-28 (1962) (Frankfurter, J., dissenting).

68. 369 U.S. 186 (1962). (1972).

69. E.g., Legislature v. Reinecke, 6 Cal. 3d 595, 492 P.2d 385, 99 Cal. Rptr. 481 
Court in $O^{\prime} B r i e n$ had at its disposal sufficient information on which to proceed.

\section{Inherently Political Questions}

Some proponents of the discretionary view have argued that matters of political controversy are inherently not capable of judicial resolution. Dissenting in Baker v. Carr, Justice Frankfurter expressed the fear that the Court was hopelessly interjecting itself into the "clasl1 of political forces in political settlements."70 Similarly, others have argued that courts should avoid cases inextricably bound up in a complex of political issues, even if the cases involve important legal issues. ${ }^{71}$ This proposition has not been consistently applied to the internal affairs of political parties, suggesting that the courts are not ill-suited to cope with at least some "political" questions. The federal courts, in the long line of the "White Primary" cases, ${ }^{2}$ flatly rejected the notion that the internal affairs of political parties are immune from judicial supervision. In O'Brien, the Supreme Court attempted to distinguish the White Primary cases from the situation of the unseated Califorma and Illinois delegates on the ground that the claims then before it were not based on racial discrimination. ${ }^{73}$ Whatever the validity of this distinction in other regards, it has no bearing on the political nature of the issues presented. The White Primary cases demonstrated the Court's competence to wade into the political waters. The reluctance in O'Brien to deal with a similar party dispute in a context devoid of a substantial constitutional infringement such as racial discrimination may suggest sub silentio an imability to confront pure intraparty struggles. If so, $O$ 'Brien's backhanded approach is less than satisfactory.

The argument that the issues in O'Brien were hopelessly political is further weakened by the Court's activity in other politically sensitive areas. In Powell v. McCormack, for example, the Court declared that Adam Clayton Powell had been unlawfully excluded from the Ninetieth Congress by the House of Representatives. ${ }^{74}$ The reapportionment cases also indicate that inquiry into the membership of state legis-

70. 369 U.S. at 186, 267 (Frankfurter, J., dissenting).

71. Bickel, supra note 59, at 70; Finkelstein, supra note 61 , at $344-45$; Jaffe, supra note 62, at 1304; Westen, Political Questions, 38 HARv. L. REv. 296, 331-32 (1925).

72. Terry v. Adams, 345 U.S. 461 (1953); Smith v. Allwright, 321 U.S. 649 (1944); United States v. Classic, 313 U.S. 299 (1941); Grovey v. Townsend, 295 U.S. 45 (1935); Nixon v. Condon, 286 U.S. 73 (1932); Nixon v. Herndon, 273 U.S. 536 (1927); Baskin v. Brown, 174 F.2d 391 (4th Cir. 1949); Rice v. Elmore, 165 F.2d 387 (4th Cir. 1947).

73. 409 U.S. at 4 n.1.

74. 395 U.S. 486 (1969). 
latures is not an inherently political question. ${ }^{75}$ No reason is advanced in $O^{\prime} B r i e n$ to view membership of delegations to party conventions similarly affected by the exercise of the franchise in a different light.

\section{Judicially Manageable Standards}

The absence of "judicially manageable standards" for deciding an issue has been advanced as a reason to describe it as "political" and nonjusticiable. ${ }^{76}$ Justice Frankfurter, for example, opposed the Court's intervention in Baker v. Carr because he did not believe the Court could fashion manageable standards for legislative apportionment. ${ }^{77}$ Justice Frankfurter concluded that the case was thus rendered "political" and unfit for judicial action. ${ }^{78}$ Professor Field anticipated this argument when he wrote: "Where no rules exist the court is powerless to act."78

This argument, however, does not support the Court's decision in O'Brien. Courts have had little difficulty resolving disputed elections for public offices, ${ }^{80}$ for positions on corporate boards of directors, ${ }^{81}$ and for union posts. ${ }^{82}$ Delegate elections should be similarly susceptible of judicial resolution.

The absence of judicially manageable standards, however, was specifically given as a prime reason for courts to avoid involvement in convention delegate disputes by the Eighth Circuit in Irish v. Democratic-Farmer-Labor Party, ${ }^{83}$ a case cited by the Supreme Court in O'Brien. ${ }^{84}$ But Irish involved much more than the resolution of a disputed delegate election. In Irish, the court rejected a petition to reap-

75. See, e.g., Wells v. Rockefeller, 394 U.S. 542 (1969); Kirkpatrick v. Preisler, 394 U.S. 526 (1969); Swann v. Adams, 385 U.S. 440 (1967); Burns v. Richardson, 384 U.S. 73 (1966); Reynolds v. Sims, 377 U.S. 533 (1964); Wesberry v. Sanders, 376 U.S. 1 (1964); Gray v. Sanders, 372 U.S. 368 (1963); Baker v. Carr, 369 U.S. 186 (1962). The Supreme Court has, however, begun to show less enthusiasm for the reapportionment cases. See, e.g., Whitcomb v. Chavis, 403 U.S. 124 (1971); Abate County v. Mundt, 403 U.S. 182 (1971); Gordon v. Lance, 403 U.S. 1 (1971).

76. Finkelstein, supra note 61, at 345; Frank, supra note 30, at 39-43; Jaffe, supra note 62 , at $1304-07$.

77. 369 U.S. 186, 267-70, 282-83, 323-24 (1962) (Frankfurter, J., dissenting).

78. Id. at 330 (Frankfurter, J., dissenting).

79. Field, The Doctrine of Political Questions in the Federal Courts, 8 MinN. L. Rev. 485, 511 (1924).

80. See Note, The Role of the Courts in Election Contest Proceedings, 48 MinN. L. Rev. 1181 (1964).

81. See E. Arranow \& H. Einhern, Proxy Contests for Corporate Control 449-537 (2d ed. 1968). Cf. Wilder v. Brace, 218 F. Supp. 860 (D. Me. 1963); In re R. Hoe \& Co., 14 Misc. 2d 500, 137 N.Y.S.2d 142 (Sup. Ct. 1954), affd, 285 App. Div. 927, 139 N.Y.S.2d 883, affd, 309 N.Y. 719, 128 N.E.2d 420 (1955).

82. See Summers, Judicial Regulation of Union Elections, 70 YALE L.J. 122 (1961).

83. Irish v. Democratic-Farmer-Labor Party, 399 F.2d 119 (8th Cir. 1968).

84. 409 U.S. at 4. 
portion Minnesota's delegation to the 1968 Democratic Convention on a one person, one vote basis, arguing that it simply could not fashion a suitable remedy. ${ }^{85}$ Could the court issue an imjunction bimding on the delegates and on the Convention? Could it order the legislature to devise a new delegate scheme with only weeks left before the start of the Convention? Could it simply impose a new scheme for selecting delegates? The Eighth Circuit seems to have doubted its ability to adopt any of these remedies. In addition, it doubted that any remedy chosen could effectuate the one person, one vote numerical equality the plaintiffs sought. ${ }^{88}$

The Supreme Court was not asked in O'Brien to decide how the delegates would be selected. It was asked simply to decide which of the California and Illinois slates had been properly selected under preexisting rules. Justice Marshall, in his dissent, properly rejected the notion that judicially manageable standards were not available in O'Brien. On the Illinois challenge the Court had only to decide whether the party's rules for selecting delegates were constitutional and then to determine whether they had been correctly apphed to the facts -questions which the Court is certainly competent to answer. ${ }^{87}$ The California challenge simply required the Court to decide whether California's "winner-take-all" primary violated the party rules and, if not, whether changing the rules after the election was permissible.

The court of appeals opinions in O'Brien and Keane demonstrate the availability of judicially manageable standards. The appellate court examined all documents relating to the reform of the delegate selection process including the resolution of the 1968 Convention that set up a reform commission, The Call to the 1972 Convention, and the rules promulgated by the reform commission. Construing these documents, the court determined that the elected McGovern slate from California and the Singer-Jackson challenging slate from Illinois should be seated. The court recognized that the integrity of the electoral process depended upon primcipled decisionmaking and application of established rules. ${ }^{88}$ Simce Califormia's primary law could not be overturned by the Convention after the election, delegates elected under the California law were seated ${ }^{89}$ Applying the same principle to the Illinois challenge, the appellate court found that the party's rules against slate-making had been clearly established before the Illinois primary. Since the 59 Daley delegates had been elected through the prohibited device of
85. 399 F.2d at 120.
86. Id. at 120-21.
87. 409 U.S. at 12 (Marshall, J., dissenting).
88. 469 F.2d 563, 570 (D.C. Cir. 1972).
89. Id. at 569 . 
slate-making, the Credentials Committee had the power to enforce the rules against the delegation. ${ }^{30}$

Far from lacking judicially manageable standards, the court of appeals opinion was a tour de force of principled decisionmaking. Faced with two different challenges-one based on state law, one based on party rules-the court resolved both disputes siniply by utilizing the established principles and rules of the party itself, of which the losing parties were clearly aware.

\section{E. Expediency}

Finally, legal scholars and jurists have sometimes put the case for the political questions doctrine on the broadest possible ground: if the court thinks it impolitic to decide a case, it should be able to avoid decision. ${ }^{21}$ It is argued that some situations are better resolved without the application of legal principles. ${ }^{22}$ This position leaves the courts, in essence, with neither standards nor limits for the exercise of their discretion.

Expediency may arguably have been a motivating factor in the Court's avoidance of the credentials disputes in O'Brien. The great difficulty with this broad discretionary view is that it has no limits and offers no basis for distinguishing between controversial cases which the Court cliooses to decide, such as the desegregation cases, and controversial cases which the Court chooses to avoid, such as O'Brien. As Justice Frankfurter said, "The line is often very thin between the cases in which the Court felt compelled to abstain from adjudication because of their 'political' nature and the cases that so frequently arise in applying the concepts of 'liberty' and 'equality." "93

A narrower, more principled version of this expediency formula has been advanced, notably by Professor Bickel. Bickel argues that society must allow for "expedient muddling through,"94 especially in periods of political flux, the courts will upset the balance of forces by which the political system arrives at a new consensus if they enforce an established but outdated absolute prineiple. On the other hand, if the courts try to enforce a pragmatic but unprincipled decision, they will violate the basis of their own authority. Bickel concludes that, in such circumstances, the Court should use its "almost inexhaustible arsenal of techniques and devices" for avoidance-the political ques-

90. Id. at 570-73.

91. Finkelstein, supra note 61 , at 344-45.

92. Jaffe, supra note 62 , at 1303 .

93. F. Frankfurter, John Marshall and the Judicial Function, 69 HARv. L. Rev. 217, 227-28 (1955), in FeLIX FranKFuRTer aNd the Supreme Court 533 (P. Kurland ed. 1970).

94. Bickex, supra note 59, at 64. 
tions doctrine, denial of certiorari, and declarations of vagueness, lack of standing, or the absence of justiciable controversy. ${ }^{95}$

Professor Bickel identifies two classes of cases in which "expedient nuddling through" is advisable: cases in which no principled decision is possible and cases in which a principled decision is possible but in which the principle should not be treated as absolute but rather only one of numerous factors to be considered in resolving the issues. ${ }^{96}$ As previously argued, ${ }^{97}$ credentials challenges do not present courts with questions in which the application of legal principles is impossible. Therefore, if Bickel's view is applicable to O'Brien, it nuust be because the case falls into his second category.

Following Bickel's analysis, an argument can certainly be made that legal principles should be merely one of the factors considered in resolving the credentials challenges. This argument would stress the effect of the Reforn Commission's guidelines on the Deinocratic Party's organization and nembership. These guidelines, which were the nub of the credentials challenges, were designed to "democratize" the party. They were designed to create a state of political flux, and they had worked. In 1972, the Denrocratic coalition was in upheaval. Labor, traditionally the backbone of the party apparatus, was virtually absent froin the Convention. The big city bosses (like Daley) were literally out; women, minorities, and young people were in. ${ }^{98}$ The reforms had acconplished their goal: they had brought new elements into the party-even though some observers, like Theodore White, thought the reforms had, in fact, created two Democratic parties. ${ }^{99}$

As Bickel might argue, the courts could decide these disputes on strictly legal considerations, but these were not the only relevant considerations. More was involved than a few seats at the Convention or than the constitutional rights of the delegates and their constituents. At stake was the future of America's majority party and, potentially, the direction in which the party would take the nation. The expediency concept would require that such nromentous issues be decided on niore than inerely legal considerations.

95. Id. at 70-71. If the Supreme Court had to abstain from deciding on the merits in $O^{\prime} B r i e n$, any technique of avoidance other than the political questions doctrine would have been preferable. The pohtical questions doctrine has the unique effect of declaring a given issue off-limits to the judiciary. The Court's other techniques of avoidance do not withdraw the issue involved from judicial scrutiny but merely foreclose the immediate parties from raismg the issue. See Scharpf, supra note 53, at 536-38. Thus, if the Court dismisses a case because of lack of standing or adversariness, better situated parties might raise the issue in the future. But the political questions doctrine absolutely prohibits judicial determination of the issue, at least, until the Court reverses itself.

96. BiCKEL, supra note 59, at 185-86.

97. See text accompanying notes 76-90 supra.

98. See WhITE, supra note 4, at 187-89.

99. Id. at 189. 
This expediency argument might have some force when applied to a case like Dred Scott $v$. Sanford, ${ }^{100}$ where a judicial decision would precipitate the breakdown of democratic order, but not when applied to cases such as O'Brien and Wigoda, where the absence of a judicial decision might permit a breakdown of democratic order. O'Brien and Wigoda concerned the fairness of democratic procedures; the electoral processes should not be compromised no matter low expedient it would be to give political forces free play without the restraints of law. When it is the rule of law itself which weighs in the judicial balance, the issues are too important to be decided by any considerations but legal principle. The next section of this Comment argues that substantial reasons support judicial intervention into the credentials disputes.

\section{IV}

\section{Why THE COURTS ShOULd INTERVENe IN CREDENTIALS DisPUTES}

Once it is acknowledged that the political questions doctrine poses no barrier to judicial resolution of intraparty disputes, substantial interests militate in favor of judicial imtervention into the credentials process. The political parties, in their role as nominators of public officials, serve a "governmental" function and should not be allowed to violate constitutional safeguards or challenge the integrity of the electoral process.

\section{A. The Governmental Role of the Parties}

In the past, courts refused to intervene in party affairs in the absence of statutory authority or compelling circumstances. ${ }^{101} \mathrm{~A}$ few courts have continued to treat political parties as if they were free to act as wholly private associations, ${ }^{102}$ and the Supreme Court in $O^{\prime} B$ rien found a "large public interest in allowing the political process to function free from judicial supervision." ${ }^{\text {103 }}$ A closer scrutiny of this laissez-

100. 60 U.S. (19 How.) 393 (1857).

101. Cf. Democratic-Farmer-Labor State Central Comm. v. Holm, 227 Minn. 52, 55, 33 N.W.2d 831, 833 (1948); State ex rel. Fosser v. Lavik, 9 N.D. 461, 83 N.W. 914 (1900). See also Annot., 169 A.L.R. 1281 (1947); Annot., 20 A.L.R. 1035 (1922).

This position was based in large part on such discredited cases as Colgrove v. Green, 328 U.S. 549 (1946). Technically, Colgrove was not overruled by Baker v. Carr, 369 U.S. 186 (1962). See BICKEL, supra note 68, at 194-97. But in light of the long line of reapportionment cases which followed Baker, e.g., Wells v. Rockefeller, 394 U.S. 542 (1969); Kirkpatrick v. Preisler, 394 U.S. 526 (1969); Swann v. Adams, 385 U.S. 440 (1967); Burns v. Richardson, 384 U.S. 73 (1966); Reynolds v. Sims, 377 U.S. 533 (1964); Wesberry v. Sanders, 376 U.S. 1 (1964); Gray v. Sanders, 372 U.S. 368 (1963); but see Whitcomb v. Chavis, 403 U.S. 124 (1971); Abate County v. Mundt, 403 U.S. 182 (1971); Gordon v. Lance, 403 U.S. 1 (1971), almost no vitality can be attributed to Colgrove.

102. Cf. Lynch v. Torquato, 343 F.2d 370, 372 (3d Cir. 1965); Smith v. State Executive Comm., 288 F. Supp. 371, 374-76 (N.D. Ga. 1968).

103. 409 U.S. at 5. 
faire approach to the political process indicates that it is no longer tenable. It is too late in our constitutional history to suggest that the function of political parties in offering candidates for public office does not involve state action. ${ }^{104}$

Political parties are not like other private associations and cannot be treated as if they were. ${ }^{105}$ Ordinary political associations, like the NAACP or the John Bircli Society, affect political decisions indirectly -by lobbying and educating the public. Political parties affect the political process directly: party nomination is the first step in the process of choosing public decisionmakers. No constitutional distinction should be made between a party choosing its nominees formally in a primary election conducted under state law or inforinally in a meeting of a self-governing club. ${ }^{106}$ In either case, the nominating process is as much "state action" as the official election.

Not all intraparty activity constitutes state action, and courts disagree on where to draw the line between the governmental and private functions of the parties. ${ }^{107}$ The internal affairs of political parties are

104. See Gray v. Sanders, 372 U.S. 368, 380 (1963); Georgia v. National Democratic Party, 447 F.2d 1271, 1275-76 (D.C. Cir.), cert. denied, 404 U.S. 858 (1971); Redfearn v. Republican State Comm., 362 F. Supp. 65, 70 (D. Del. 1973); Miller v. Bartunek, 349 F. Supp. 251, 253 (N.D. Ohio 1972), vacated \& remanded, 480 F.2d 927 (6th Cir. 1973). See also Raymar, supra note 3, at 18-20; Note, One Man, One Vote and the Selection of Delegates to National Nominating Conventions, 37 U. CH. L. Rev. 536, 538-45 (1970); Note, Constitutional Safeguards in the Selection of Delegates to Presidential Nominating Conventions, 78 Y ALE L.J. 1228, 1232-35 (1969) [hereinafter cited as Safeguards].

105. The Fourth Circuit has indicated some of the distinguishing characteristics of political parties:

The party may, imdeed, have been a mere aggregation of individuals in the early days of the Republic, but with the passage of the years, political parties have become in effect state institutions, governmental agencies through which sovereign power is exercised by the people.

Rice v. Elmore, 165 F.2d 387, 389 (4th Cir. 1947), cert. denied, 333 U.S. 875 (1948).

106. See Terry v. Adams, 345 U.S. $461,468-70$ (1953). There the Supreme Court ruled that a primary held by a self-governing club, ostensibly independent of both the official party organization and the state government, involved stated action.

107. The District of Columbia Circuit held that the delegate selectiou procedures involve state action in two cases, Georgia v. National Democratic Party, 447 F.2d 1271 (D.C. Cir.), cert. denied, 404 U.S. 858 (1971), and Bode v. National Democratic Party, 452 F.2d 1302, 1304-05 (D.C. Cir. 1971), cert. denied, 404 U.S. 1019 (1972), although the court did not overturn existing party procedures im either case. The plaintiffs iu the Georgia case sought to establish that convention delegates must be apportioned among the states on the basis of state population, but the court rejected their appeal on the ground that the constituency of a state political party is not so directly related to state population that the National Convention was required to apply the one person, one vote rule. 447 F.2d at 1278-80. In Bode, the Court overturned a district court decision holding unconstitutional the weighting of votes at the Democratic National Convention in favor of states that had gone Democratic in the previous Presidential election; the Court would not accept a "one Democrat, one vote" principle derived from the reapportionment cases. 452 F.2d at 1305-06. In Redfearn v. Republican State Comm., 362 
probably best thought of as a continuum from obviously governmental functions such as running candidates for public office to purely housekeeping functions such as selecting party functionaries. The basic question in all cases is whether the particular function constitutes a significant step toward determining who will be elected to public office. ${ }^{108}$

State action is not involved in a party's housekeeping functions, and courts can not justify intervention into such strictly internal matters as the election of party ineinbers to a committee that has no significant control over the nomination of candidates for public office. ${ }^{100}$ On the other hand, it is clear that state action is involved in party primary procedures. ${ }^{110}$ A delegate selection procedure unfairly biased in favor of a particular constituency or one that countenances the effective freezing out of insurgent groups by party leaders affects the basic machinery by which a party candidate and the ultimate office-holder is chosen. Arguably, delegate selection caucuses are functionally indistinguishable from party primary procedures and should be considered to involve state action as well, although judicial intervention into a party's governmental functions is not without limits. ${ }^{111}$

Two companion cases decided by a Washington federal district court are consistent with this analysis. In Maxey $v$. State Democratic Committee, the court found that state action was involved in the Washington Democratic Party's procedure for selecting delegates to the national convention and imsisted that the party apply one person, one vote principles. ${ }^{112}$ In Dahl v. Republican State Committee, the court refused to apply the same equal protection arguments to a statutory pro-

F. Supp. 65, 70 (D. Del. 1973), the district court found state action in the Delaware Republican Party's delegate selection procedures.

In Lynch v. Torquato, 343 F.2d 370, 372-73 (3d Cir. 1965), the court found no state action involved in Pennsylvania's procedure for allowing Democratic County Central Committeo members, who wcre popularly elected, to select the County Chairman, but the court left open the question of whether state action was involved in the party's procedures for nomination of candidates for public office. In Smith v. State Executivo Comm., 288 F. Supp. 371, 374 (N.D. Ga. 1968), the court found no state action involved and refused to apply one person, one vote principles to Georgia's procedure for selecting delegates to the Democratic National Convention.

108. Cf. Seergy v. Republican County Comm., 459 F.2d 308, 313-14 (2d Cir. 1972).

109. Lynch v. Torquato, 343 F.2d 370, 372 (3d Cir. 1965).

110. See Safeguards, supra note 104, at 1233-35.

111. Judicial intervention into the parties' governmental functions is limited in soveral ways. First, courts can review only procedural decisions made by a political party (e.g., low the party's candidate will bo selected). They cannot review substantive decisions (like the substance of the party platform). Second, even where procedural decisions are involved, the courts can determine only whether a party's procedures are unconstitutional. The courts are not asked to make an affirmative judgment on the value of the party rulcs.

112. 319 F. Supp. 673, 679 (W.D. Wash. 1970). 
cedure for electing party officers and found that no state action was involved. ${ }^{113}$

\section{B. The Rights and Interests at Stake in Delegate Selection Procedures}

Since the states establish the election laws under which convention delegates are selected, they have an obvious interest in preserving the integrity of their laws and resisting unlawful activity by poitical parties. ${ }^{114}$ In Wigoda $v$. Cousins, the Illinois appellate court rested the case for judicial intervention on this point. The court said: "The rights acquired and the duties imposed by the primary election laws are valuable and important not only to those who acquire them under the law, but to the entire people of the State."115 Under Illinois law the delegates acted as "the legal representatives . . . of the people at the Convention."116 Consequently, the court found judicial imtervention necessary to protect the state's interest in its own election laws: "The interest of the state in protecting the effective right to participate in primaries is superior to whatever other interests the party itself might wish to protect." 117

The Illinois court in Wigoda also cited the "legal rights" of the challenged delegates as support for judicial intervention. ${ }^{118}$ The source of these "legal rights" is not entirely clear. The Illinois court thought that "[t]he right to sit as a delegate representing Illinois at the national nominating convention is governed exclusively by the Hinois Elections Code." 110 This exclusivity concept, however, cannot be wholly correct, since inany decisions regarding the qualifications and required party affiliation of a delegate devolve to the party itself. ${ }^{120}$ The conflicts between national party rules and state laws, discussed in Part V of this Comment, have not been definitively resolved by the courts. ${ }^{121} \mathrm{Re}-$ gardless of their alleged exclusivity, the state election laws clearly con-

113. 319 F. Supp. 682 (W.D. Wash. 1970).

114. Cf. American Party v. White, 94 S. Ct. 1296, 1307-09 (1974); Storer v. Brown, 94 S. Ct. 1274, 1282 (1974); Kusper v. Pontikes, 414 U.S. 51, 59 (1973); Rosario v. Rockefeller, 410 U.S. 752, 761-62 (1973).

115. 14 Ill. App. 3d at 474, 302 N.E.2d at 627, quoting State ex rel. Merrill v. Gerow, 79 Fla. 804, 85 So. 144, 146 (1920).

116. 14 Ill. App. 3 d at 475,302 N.E.2d at 628 .

117. Id. at 477,302 N.E.2d at 629 .

118. Id. at $472,474,475,302$ N.E.2d at $624-25,627,628$.

119. Id. at 472,302 N.E.2d at 626 .

120. In several recent cases the Supreme Court recognized that "the integrity of the electoral process" depends upon the prevention of "interparty raiding." Storer v. Brown, 94 S. Ct. 1274, 1279-80 (1974); American Party v. White, 94 S. Ct. 1296, 1308 (1974); Kusper v. Pontikes, 414 U.S. 51, 59-60 (1973); Rosario v. Rockefeller, 410 U.S. 752, 761 (1973).

121. See Mandates, supra note 3, at 158-63. 
fer some rights on the elected delegates, and these rights deserve judicial attention. ${ }^{122}$

Arguably, the first amendment rights of freedom of political activity and association are also involved. The Singer-Jackson delegates Inade this argument in the appellate court in Wigoda, but the court found the reasoning "shallow." The Supreme Court in O'Brien, on the other hand, found that "[v]ital rights of association guaranteed by the Constitution are also involved."124 Whether the courts should have found that the asserted rights were involved in this case is arguable, but certainly the "vital rights of association" are entitled to judicial attention.

The rights of the voters of California and Illinois were also at stake in the credentials cases. By denying seats to the elected delegates the Credentials Committee may have denied due process to their electors who might otherwise have cast their votes differently. ${ }^{125}$ The voters' right to an orderly election was cited by the court in Wigoda as a basis for judicial intervention. ${ }^{128}$

The interests of the states, the delegates, and the voters are of sufficient gravity to justify judicial intervention into the credentials disputes. But above all these particular interests is the over-arching interest in the integrity of the political process. As the District of Columbia Circuit said in O'Brien: "[T] he process of electing the President of the United States is not, and cannot be, placed outside the rule of

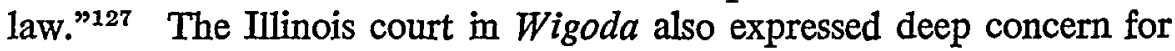
the integrity of the electoral process:

We think the Convention, a voluntary association, was without power or authority to deny the elected delegates their seats in the Convention and most certainly could not seat people of their choice and force them upon the people of Illinois as their representatives, contrary to their elective mandate. Such action is an absolute destruction of the democratic process of this nation and cannot be tolerated. ${ }^{128}$

The courts which authored these opinions disagreed on the course of action to be taken, but they agreed judicial action was necessary to res-

122. The importance of the legal claims of the challenged delegates is even more clear in the California situation. The challenged California delegates were duly elected under state law and under existing party rules. In order to unseat them, the Credentials Committee had to act "in defiance of its own rules." Brown v. O'Brien, 469 F.2d 563, 569 (D.C. Cir. 1972).

123. 14 IIl. App. 3d at 471,302 N.E.2d at 625 .

124. 409 U.S. at 4.

125. Brown v. O'Brien, 469 F.2d 563, 569 (D.C. Cir. 1972).

126. 14 IIl. App. 3d at 476, 302 N.E.2d at 628.

127. Brown v. O'Brien, 469 F.2d 563, 570 (D.C. Cir. 1972).

128. 14 III. App. $3 d$ at 479,302 N.E.2d at 631 . 
cue the electoral system from "the arbitrary and unconstitutional action of the Democratic Party."128 These two courts tacitly recognized what the Supreme Court failed to acknowledge in O'Brien: the political rights of the voters had been sacrificed by the Convention and would continue to be jeopardized by politicians in the interests of partisanship and power. ${ }^{130}$ The lower courts correctly insisted upon judicial action in the credentials disputes. The real issue, as the disagreement between these two appellate courts emphasizes, is not whether judicial action should be taken, but what judicial action should be taken.

\section{V \\ TOWARD A MORE WORKable RESOLUTION OF Credentials Disputes}

The political questions doctrine does not warrant judicial abstention in cases involving credentials disputes. Courts must squarely face the merits of cases like O'Brien and Wigoda. Judicial intervention in credentials disputes is likely to be sought in at least two contexts: where the procedure for selecting delegates is challenged on constitutional grounds, and, as in O'Brien, where a particular slate of elected delegates is challenged on the ground of noncompliance with either party rules or state law. The first problem-constitutional challenges to delegate selection procedures-has received adequate attention from the courts ${ }^{131}$ and the commentators. ${ }^{132}$ The problem of challenges to particular delegations, lowever, has been largely ignored.

129. Brown v. O'Brien, 469 F.2d 563, 570 (D.C. Cir. 1972).

130. The "official" chronicler of Presidential contests gives a detailed account of the proceedings in the Credentials Committee. WHITE, supra note 4, at 171-76. White's verdict on the Committee's California ruling: "It is dirty; it is cold politics; a handful of people manipulating a committee of 150 individuals has denied the validity of the law and voting of California, a state of $20,000,000$ people." Id. at 173 . The decision reached on the Convention floor (the "proper forum" for decision, the Supreme Court had called it) was equally unprincipled and power-motivated. For an account of the floor fights on the credentials challenges, see id. at 178-86; N. MAILER, ST. GEORGE AND THE GODFATHER at 35-46 (Signet ed. 1972).

131. See, e.g., Republican State Central Comm. v. Ripon Soc'y, Inc., 409 U.S. 1222 (1972) (Rehnquist, Circuit Judge); Bode v. National Demoratic Party, 452 F.2d 1302 (D.C. Cir. 1971); Georgia v. National Democratic Party, 447 F.2d 1271 (D.C. Cir. 1971); Irish v. Democratic-Fanner-Labor Party, 399 F.2d 119 (8th Cir. 1968); Lynch v. Torquato, 343 F.2d 370 (3d Cir. 1965); Redfearn v. Republican State Comm., 362 F. Supp. 65 (D. Del. 1973); Maxey v. State Democratic Comm., 319 F. Supp. 673 (W.D. Wash. 1970); Smith v. State Executive Comm., 288 F. Supp. 371 (N.D. Ga. 1968).

132. See, e.g., Blumstein, supra note 3; Chambers \& Rotunda, Reform of Presidential Nominating Conventions, 56 VA. L. REv. 179 (1970); Schmidt \& Whalen, Credentials Contests at the 1968 and 1972 Democratic Conventions, 82 HARv. L. REv. 1438 (1969); Note, One Man, One Vote and Selection of Delegates to National Nominating Conventions, 37 U. CHI. L. REv. 536 (1970); Safeguards, supra note 104. 
This is partly because many major credentials disputes have not reached the courts (for example, the Taft-Eisenhower battles at the 1952 Republican Convention and the seating of the Mississippi Freedom Delegation at the 1964 Democratic Convention) and partly because the courts have usually adopted a hands-off attitude toward credentials disputes (as in O'Brien). The judicious resolution of the merits of cases such as $O^{\prime} B r i e n$ requires that principles be articulated on which sucli decisions may be grounded.

There are two basic situations in which the courts may be asked to judge the makeup of a particular delegation. First, a delegation selected by procedures which comply with both the party rules and state law may nevertheless be unseated by the credentials committee. This was the experience of the California delegation at the 1972 Democratic Convention, and for convemence it will be referred to as the "Califormia situation." Second, a delegation selected by procedures which complied with state law but not with a conflicting party rule may be unseated by the credentials committee. This was the experience of the Illinois delegation at the 1972 Democratic Convention, and for convenience it will be referred to as the "Illinois situation." The following discussion suggests legal principles which might be applied in each of these situations.

\section{A. The California Situation}

In the California situation the delegate selection process satisfies both the state law and the announced party rules. The legal principle to be applied in this situation is clear: the elected delegates should be seated, and no challenge should be recognized as valid. In order to unseat such delegates at the convention, the party rules would have to be changed after the delegate selection process had been completed, and this should be impermissible. As the District of Columbia Circuit said in its original opinion in Brown v. O'Brien:

[T] here can be no dispute that the very integrity of the [electoral] process rests on the assumption that clear rules will be established, and that, once established, they will be enforced fairly, consistently and without discrimination so long as they remain in force. ${ }^{133}$

\section{B. The Illinois Situation}

In Wigoda the Illinois appellate court found a direct conflict between the state election laws and the party rules. ${ }^{134}$ The District of Columbia court, lowever, had earlier characterized the Illinois challenge quite differently. It found that the state law and party rules

133. 469 F.2त at 570 (D.C. Cir. 1972).

134. Wigoda v. Cousins, 14 Ill. App. 3d 460, 475, 302 N.E.2d 614, 627 (1973). 
"complemented" one another simce Illinois law was silent on the contested issue of "slatemaking." interpretations of the Illinois situation may be more apparent than real. Where the state law and the party rules are not expressly congruent (as they were in the California situation), conflict between them is a possibility. This conflict ripens when the state permits certification of a convention delegation which does not fulfill the requirements of party rules. In countenancing the qualification and certification of a delegation which had been slated, the Illinois election law was no longer truly silent on the slate-making issue, but had effectively validated the practice. Since slate-making was impermissible under the party rules, a choice between state law and party rules was inescapable before either Illinois delegation could be recognized.

Five approaches may be suggested for resolving conflicts between party rules and state law; the Supreme Court should choose one in its review of Wigoda.

\section{The States' Rights Approach}

According to the states' rights approach, state laws prevail over party rules where there is a conflict. The advocates of this approach argue that unless state election laws prevail over party rules the right to vote is abridged. ${ }^{136}$ For example, the Daley delegates argued in their brief to the Supreme Court that they represented the will of the Illinois voters and that the party's interest in enforcing its reforms was insufficient to "disenfranchise" 700,000 Illinois voters. ${ }^{137}$

This approach, however, is inappropriate. First, the states' rights approach is unsound as a matter of law. The right to vote is not absolute. ${ }^{138}$ The Supreine Court has recognized, for example, that voters may be disqualified from voting in primaries for reasonable periods of time after changing their party affiliation. ${ }^{139}$ Likewise, voters should not have the right to vote for unqualified candidates imder the states' rights approach. ${ }^{140}$ Moreover, it may be argued that the states' rights approach violates contemporary notions of constitutional freedoin of political association. ${ }^{141}$ The first amendment guarantees that political

135. Brown v. O'Brien, 469 F.2d 563, 572 (D.C. Cir. 1972).

136. See Mandates, supra note 3, at 159.

137. Petitioner's Brief for Writ of Certiorari at 26, O'Brien v. Brown, 409 U.S. 1 (1972).

138. Cf. Rosario v. Rockefeller, 410 U.S. 752 (1973).

139. Id. at 762 .

140. The Illinois court in Wigoda attempted to establish the states' rights approach as a legal principle on the basis of some very old precedents. See Wigoda v. Cousins, 14 Ill. App. 3d 460, 474-76, 302 N.E.2d 614, 627-28 (1973).

141. Williams v. Rhodes, 393 U.S. 23,30 (1968). 
parties will have considerable freedom to regulate their own affairs. ${ }^{142}$ Should a party choose to nominate its candidates for public office through a convention procedure, rather than through a primary, the state cannot require the party to hold a primary in order to qualify itself for a place on the ballot. ${ }^{143}$

Second, the states' rights approach is unsound as a matter of policy. The party would be greatly hampered in any effort to adopt democratizing reforms by the need to qualify its procedures under the laws of 50 states; procedures which maximize voter participation in party affairs almost invariably must be uniform among all the states in order to be effective. "Undemocratic" procedures, like the "winnertake-all" primary or the unit rule, are traditionally used to maximize the strength of the particular state's delegation at the convention by eliminating the possibility of factionalism, affording the state's votes their optimum impact. Adoption of such a technique by some states discourages other states from enacting more democratic procedures. Thus uniformity of procedural rules among the state parties is not only desirable but often imperative. The states' rights approach would be an unfortunate, probably unconstitutional roadblock to party reform and it should not be adopted.

\section{The Party-First Approach}

According to the party-first approach, party rules always prevail over state laws where there is a conflict. This approach has been urged by one cominentator on the ground that the election of the President is "not a mere state interest but a crucial national interest" and that the individual states should not be able to interfere "in the formulation of national policies in the vital elimination process of Presidential candidates."144 As noted above, there is great need for uniformity at the national conventions, and as a strict matter of policy, the party-first approach has great appeal.

Recent decisions of the Supreme Court make it quite clear, however, that the first amendment does not protect the parties from all state regulation. The Court has said:

[A]s a practical matter, there must be a substantial regulation of elections if they are to be fair and honest and if some sort of order, rather than chaos, is to accompany the democratic processes. In

142. The fact that the political parties' nominating function involves state action does not mean that they are subject to complete regulation by the state or that they forfeit all rights of private action. It means only that they are subject to the limitations imposed by the Constitution on governmental bodies when they are performing their public functions.

143. Williams v. Rhodes, 393 U.S. 23, 32-33 (1968).

144. Mandates, supra note 3 , at 160. 
any event, the States have evolved comprehensive and in many respects complex election codes regulating in most ways, with respect to both federal and state elections, the time, place and nnanner of holding primary and general elections, the registration and qualification of voters and the selection and qualification of candidates. It is very unlikely that all or even a large portion of the state election laws would pass muster under our cases. . . . 145

Obviously the party-first approach is as unacceptable as the states' rights approach. Courts must accommodate both the state's interest in orderly elections and the party's right to free political association.

\section{The Estoppel Approach}

Under the estoppel approach, delegate candidates who do not comply with party rules may be challenged before the delegate selection procedure but not after. This approach is a compromise position based on considerations of timing. The theory is that if neither the state nor the party can prevail all of the time, then each of thein should prevail some of the time. Before an election, a challenge to the candidacy of a delegate unqualified under the party rules would be recognized. If such a challenge were brought before an election and found to be valid, the court would order that the candidate's name be removed from the ballot. Such a challenge could be brought either by the opposing candidates or by the party, since both have an obvious interest in enforcing the party rules. If no challenge were brought before an election, the possibility of a challenge based on the party rules would be foreclosed. The state law, though inconsistent, would determine the final result. Having failed to challenge the qualifications of the elected delegates while remedies which would not cloud the electoral mandate were still available, the challengers and the party would be "estopped" from objecting to the application of state law.

This approach would theoretically solve the problen of seating "qualified" unelected delegates who did not represent an electoral mandate. Certainly this is not a hypothetical problem. The possibility is very real that delegates pledged to candidate $X$ will be replaced by delegates pledged to candidate $Y$ if candidate $Y$ 's supporters control the Credentials Committee. The temptation for a dominant faction on the Credentials Committee to engage in such manipulations is often irresistible when the votes are needed.

But another tool-a constructive trust imposed upon unelected delegates who successfully challenge the credentials of the elected delegates-is available to the courts to ensure that the mandate of the voters is observed. Therefore, the costs under the estoppel approach of

145. Storer v. Brown, 94 S. Ct. 1274, 1279 (1974). 
achieving a theoretical finality of election results by making the timing of the challenge the dispositive factor should be carefully examined.

The estoppel approach would create many administrative problems. A strict estoppel rule is likely to foreclose meritorious challenges. Often a candidate's lack of qualifications will not come to hight until after an election. Even where disqualifying facts are known, they may not be susceptible of immediate proof or there may be extenuating circumstances. An additional administrative problem is presented by the availability of two forums for the credentials challenge-the party committee and the courts. The O'Brien opinion suggests that a challenge would not be ripe for adjudication at least until the Credentials Committee had the opportunity to review the matter. ${ }^{146}$ A problem would develop, however, if a challenge were raised in the Credentials Committee before an election but not acted upon by the Committee until after the election. Does the occurrence of the election automatically meet the challenge under the estoppel approach? Since the approach is basically a refinement of equitable principles, the answer should be no: a challenge should be preserved beyond the date of an election if it were brought in good faith before an election and left unresolved through no fault of the challenger. But were that the case, the estoppel approach would not achieve the finality of election results which was its raison d'être.

\section{The Substance/Procedure Approach}

According to the substance/procedure approach, party rules prevail on the substantive qualifications of delegates, but state law prevails on procedural matters. This approach has the virtue of familiarity. It is based on a test which, though never entirely clear, is one that courts are accustomed to applying. The substance/procedure approach even appears to have the enlightened virtues of natural order. The state and the party each acts within its own sphere of competence; the state estabhishes procedural rules to govern elections, and the party establishes substantive qualifications to determine its membership.

Putting aside the traditional haggling over where to draw the line between substance and procedure, the following hypothetical situation shows the ease of applying this rule. A party guideline outlaws the unit rule at all levels of the delegate selection process. State $\mathrm{X}$ has a law requiring that the unit rule be applied in all party caucuses within the state. Applying the substance/procedure approach, a rule which determines how the balloting will take place and not who will do the balloting is a procedural rule. Since state law prevails on all procedural matters, the unit rule is applied and the party guideline is ignored.

146. O’Brien v. Brown, 409 U.S. 1, 4-5 (1972). 
Despite its simplicity, the substance/procedure approach is open to the same objections as the states' rights approach. If the states prevail absolutely, even in the limited area of procedural rules, the national party organization potentially will be subject to 50 different election laws, and uniformity in the delegate selection process may be totally sacrificed.

Language in several recent Supreme Court cases, however, suggests that the Court would support the substance/procedure approach despite these pohicy considerations. The Court has found that "as a practical matter" the states must play a regulatory role in order to assure that the electoral process is conducted in a fair and orderly manner. ${ }^{147}$ The state also has an interest in assuring that elections will be "manageable."148 To protect this interest states may require parties to file petitions signed by a reasonable number of voters in order to qualify for a place on the ballot ${ }^{149}$ and may require voters to register with a party in advance to qualify to vote in the party election. ${ }^{150}$ Thus the Court seems to have given the states broad discretion to supervise electoral procedures in a nnanner suggesting some amenability to the substance/procedure compromise.

Nevertheless, allocating all procedural issues to the states may give too broad a reading to the Court's opimions in the elections cases, since it has actually given the states a limited managerial role in determining election procedures. State regulations can only be justified by the state's interest in "keeping its ballots within manageable, understandable limits"151 and in eliminating "frivolous candidacies."152 The state's power to impose procedural electoral regulations is not plenary, being limited by the boundaries of first amendment protections.

Thus in Rosario v. Rockefeller ${ }^{153}$ the Supreme Court upheld a New York law which required party registration by a voter 11 months prior to the election as a prerequisite to voting in the party primary. A few months later, however, in Kusper v. Pontikes ${ }^{154}$ the Court denied effect to a similar Illinois statute where the deadline for changing party registration was 23 nuonths prior to the primary date. In Rosario,

147. Storer v. Brown, 94 S. Ct. 1274, 1279 (1974).

148. Lubin v. Panish, 94 S. Ct. 1315, 1319 (1974); Bullock v. Carter, 405 U.S. 134, 144-45 (1972).

149. American Party v. White, 94 S. Ct. 1296 (1974); Jenncss v. Fortson, 403 U.S. 431 (1971).

150. Rosario v. Rockefeller, 410 U.S. 752 (1973); cf. Kusper v. Pontikes, 414 U.S. 51,59 (1973).

151. Lubin v. Panish, 94 S. Ct. 1315, 1319 (1974); Bullock v. Carter, 405 U.S. 134, 144-45 (1972).

152. Bullock v. Carter, 405 U.S. 134, 145 (1972).

153. 410 U.S. 722 (1973).

154. 414 U.S. 51 (1973). 
the Court found that the New York statute was "tied to [the] particularized legitimate purpose" of preventing interparty raiding which might disrupt the electoral process. ${ }^{155}$ In addition, the New York statute did not infringe first amendinent rights of political association since it was not a genuine obstacle to affiliation with a political party. ${ }^{160}$ But the Illinois law in Kusper was found to infringe the "basic constitutional liberty" of political association; moreover, it was not justified by any particularized state interest. ${ }^{157}$ The distinction between Rosario and Kusper deinonstrates that the Court does not conceive of the state's function as a broad, sweeping power to oversee the political process. A state regulation of elections is valid only when it is tied to the limited purpose of protecting the orderliness of elections.

The Supreme Court's opinions in four cases involving minority parties' efforts to qualify for a ballot position in a general election have followed the same principle. In two of the cases, the Court invalidated state laws which required parties to collect a high number of voters' signatures in order to qualify for the ballot. ${ }^{158}$ In the other two cases, the state laws were less restrictive and were upheld. ${ }^{160}$ The Court rejected the strict laws as infringements of the constitutional freedom of political association. ${ }^{160}$ In contrast, the less restrictive laws were found to serve the states' interest in preserving the orderliness of elections. ${ }^{101}$

Under the Court's analysis, where the state's interest in the orderliness of elections is not threatened, state regulation of pohtical association is not justified. A conflict between state law and party rules cannot always be resolved by the substance/procedure approach since such an analysis would allocate all procedural decisions to the state, regardless of the state's interest. What is needed is an approach which recognizes both the state's interest in the orderliness of its elections and the fundamental interest of the parties in the freedom of political association.

\section{The Modified Party-First Approach}

According to the modified party-first approach, party rules always prevail over state laws, except where the party rules conflict with the

155. 410 U.S. at 761-62.

156. Id. at 762 .

157. Kusper v. Pontikes, 414 U.S. 51, 61 (1973).

158. Storer v. Brown, 94 S. Ct. 1274 (1974); Williams v. Rhodes, 393 U.S. 23 (1968).

159. American Party v. White, 94 S. Ct. 1296 (1974); Jenness v. Fortson, 403 U.S. 431 (1971).

160. Storer v. Brown, 94 S. Ct. 1274, 1287 (1974); Williams v. Rhodes, 393 U.S. 23, 30-31 (1968).

161. American Party v. White, 94 S. Ct. 1296, $1308-09$ (1974); Jenness v. Fortson, 403 U.S. 431, 439, 441 (1971). 
state's interest in manageable elections. This approach recognizes both the substantial rights of political associations and the interests of the states in orderly elections. The political parties would ordinarily be free, within constitutional limits, to adopt procedural and substantive rules for their own governance. The first amendment seems to require no less. ${ }^{162}$ The states, however, would also play a role in assuring the inanageability of electoral contests.

Under this approach, if the national party decided to abolish the unit rule at all levels of the delegate selection process, and state law required the application of the unit rule in political caucuses, the party rule would prevail since the state's interest in the orderliness of the electoral process would not be threatened by the party's rule. The delegate selection process would be manageable with or without the unit rule, and the state's attempt to impose it on the political party would violate protected first amendinent imterests. On the other hand, if state law required convention delegate candidates to collect a specified number of signatures on a petition in order to qualify for a place on the ballot, the state law would prevail over the party rule since the state's interest in an orderly election would justify the imposition of reasonable tests of the seriousness of a candidacy. ${ }^{16:}$

This modified party-first approach has one significant drawback. If the party rules are to govern in normal circumstances, elected delegates whose selection procedures have not fulfilled the party requirements may be successfully challenged and replaced by a slate of delegates who support a different candidate from the one to whoin the elected delegates had been committed. This may displace the electoral mandate of the voters. To remedy this contingency, however, courts might view the convention delegates as fiduciaries, liolders of a public trust. If a committed slate of elected delegates were replaced by an alternative delegation under the modified party-first approach, the courts should impose a constructive trust on the alternative delegation and require thein to vote in a manner consistent with the mandate issued to the delegation by the electorate. In imposing such a constructive trust, of course, the courts should be mindful of the need for flexibility in the political system; they should not so restrict the discretion of the trustees that they, as delegates, would be unable to respond to critical changes in the political situation. The primary objective of the courts in fashioning a reinedy should be to fulfill, as nearly as possible, the expectations of the voters and the requirements of state law with regard to the commitment of elected delegates.

162. Cf. Williams v. Rhodes, 393 U.S. 23, 30 (1968).

163. Balancing tests have often been applied in the elections area by the Supreme Court. See, e.g., Dunn v. Blumstein, 405 U.S. 330, 335, 348 (1972); Williams v. Rhodes, 393 U.S. 23, 30 (1968). 
The constructive trust remedy has considerable merit as a matter of policy. The incentive for a dominant faction to eliminate opposition delegates would be diminished. Furthermore, it would provide an incentive for the adoption by the party of rules requiring the delegates to commit themselves to a candidate in advance of an election, thereby enabling a more informed and enforceable voter choice at the polls. The inodified party-first position protects the interests of the voters in a meaningful electoral mandate, while protecting the party's and the delegate's interests in the freedom of political association and the state's interest in an orderly, manageable election.

\section{CONCLUSION}

The Supreme Court should not have raised the spectre of the political questions doctrine in O'Brien $v$. Brown. It did so without any theoretical justification and in nearly coinplete disregard of the interests which called for a resolution of the credentials disputes in a judicial forum. The Court may have feared that if it intervened in the credentials disputes, it would give the appearance that the justices were choosing sides between the presidential candidates and that its decision was politically notivated. But in cases like these, any decision, even a decision not to intervene, may appear politically motivated. The Court can avoid these appearances only by a principled effort to address the legal issues raised by the cases, an effort which the Court in O'Brien refused to inake.

The courts, however, are not without legal principles on which to base a decision in credentials cases, and they should reach the merits of the legal claims involved. When the Supreme Court again addresses the problem of the credentials cases in its review of Wigoda, the justices should inake it clear that intraparty disputes do present justiciable questions and that the lower courts should use the available legal primciples to decide sucl cases when their jurisdiction is invoked. Only then could it no longer be said that when you ask a political question, you get a political answer. 